\title{
Effects of Energy Cane (Saccharum spp.) Juice on Corn Ethanol (Zea mays) Fermentation Efficiency: Integration towards a More Sustainable Production
}

\author{
Pietro Sica *, Laysa Maciel Lewandowski Meira Prado, Pedro Granja, Elias Miguel de Carvalho, \\ Eduardo de Castro Mattos, Rubens Perez Calegari, Manuella Silverio, Bianca Chaves Martins \\ and Antonio Sampaio Baptista
}

Citation: Sica, P.; Prado, L.M.L.M.; Granja, P.; Carvalho, E.M.d.; Mattos, E.d.C.; Calegari, R.P.; Silverio, M.; Martins, B.C.; Baptista, A.S. Effects of Energy Cane (Saccharum spp.) Juice on Corn Ethanol (Zea mays)

Fermentation Efficiency: Integration towards a More Sustainable

Production. Fermentation 2021, 7, 30.

https://doi.org/10.3390/

fermentation7010030

Academic Editor: Thaddeus Ezeji

Received: 31 December 2020

Accepted: 18 February 2021

Published: 22 February 2021

Publisher's Note: MDPI stays neutral with regard to jurisdictional claims in published maps and institutional affiliations.

Copyright: (c) 2021 by the authors. Licensee MDPI, Basel, Switzerland. This article is an open access article distributed under the terms and conditions of the Creative Commons Attribution (CC BY) license (https:/ / creativecommons.org/licenses/by/ $4.0 /)$.
College of Agriculture "Luiz de Queiroz", University of Sao Paulo, Padua dias Avenue, 11, Piracicaba, SP 13418900, Brazil; laysa.prado@usp.br (L.M.L.M.P.); pedro.granja@usp.br (P.G.); elias.carvalho@usp.br (E.M.d.C.); eduardo.castro.mattos@usp.br (E.d.C.M.); rubenscalegari@live.com (R.P.C.); manuella.silverio@gmail.com (M.S.); martins.bianca92@gmail.com (B.C.M.); asbaptis@usp.br (A.S.B.)

* Correspondence: pietros0394@gmail.com

Abstract: Despite being considered renewable, corn (Zea mays) ethanol still generates much debate over the use of fossil fuels in its production and is considered less sustainable than sugarcane (Saccharum spp.) ethanol. In Brazil, corn ethanol is starting to be produced in the Center-West and is expected to increase with the RenovaBio, a promising policy for biofuels adoption. In this context, energy cane (Saccharum spp.) is a biomass crop with high yields that can provide bagasse to supply the energy demand of the corn ethanol industry and provide juice with about $10 \%$ sugar content. However, the effects of introducing its juice in the production process are unknown. For these reasons, the objective of this study was to assess the effects of adding energy cane juice in corn ethanol production. Energy cane juice brings several advantages: (i) It provides sugars that can reduce by almost $50 \%$ the amount of corn and enzymes used, (ii) reduces the amount of water needed for ethanol production, and (iii) increases significantly the fermentation efficiency from $86.4 \%$ to $90.8 \%$ by providing minerals that support yeast growth. Therefore, energy cane can be integrated into the corn ethanol production process, making the fermentation more efficient and the production systems more sustainable.

Keywords: biofuels; RenovaBio; fermentation efficiency; energy cane; bioethanol; alcohol

\section{Introduction}

In 2005, Brazil [1] and the USA [2] produced about 15.8 million $\mathrm{m}^{3}$ and 14.8 million $\mathrm{m}^{3}$ of ethanol, respectively. By 2019, Brazil had more than doubled its production to 35.6 million $\mathrm{m}^{3}$ [1], while the United States almost quadrupled its production, to 59.8 million $\mathrm{m}^{3}$ [3]. The Renewable Fuel Standard (RFS) is a federal program in the USA that originated with the Energy Policy Act of 2005 and expanded by the Energy Independence and Security Act of 2007. This program requires that the amount of renewable fuel blended into transportation fuel should increase each year until 2022, emitting lower levels of GHGs [4,5] and using the Renewable Identification Numbers (RINs) as credits for renewable fuels producers [6]. These initiatives led to an increase in corn (Zea mays) ethanol produced in the USA. In Brazil, the corn ethanol demand is expected to grow with the federal program RenovaBio [7]. In the RenovaBio, biofuel producers will receive one financial title equivalent to carbon credits called $\mathrm{CBIO}$, which corresponds to one ton of $\mathrm{CO}_{2}$ that is no longer emitted due to the biofuel production. Fuels distributors will have an obligation to buy CBIOs, and it will also be available to any interested investor $[8,9]$.

For the RenovaBio program, a system's energy balance is an important indicator. Energy balance is the ratio of the energy released by burning the biofuel to the energy used 
in its production process. In the sugarcane (Saccharum spp.) ethanol produced in Brazil, bagasse is generated and used for cogeneration of energy, of which $40 \%$ is enough to supply the plant's demand and $60 \%$ is the commercialized surplus [10]. In the US, corn is the most common feedstock for ethanol production and, according to different studies, has shown a range of energy balances from slightly negative to slightly positive balance. One of the main differences between ethanol production systems from sugarcane and corn is that by employing sugarcane, it is possible to use the sugarcane bagasse for energy generation. As for the corn, no vegetable biomass becomes available for that purpose and fossil fuels such as coal and natural gas are commonly employed to supply the plant energy demand, which decreases its energy balance. The energy balance of the Brazilian sugarcane ethanol is from 8.3 to 10.6 whereas the American corn ethanol is from 1.3 to 1.6 [11-13].

Brazil is the third-largest corn producer in the world. In 2019, aggregated maize production in Brazil was forecasted at a near-record level of 95.2 million tons [14]. The state of Mato Grosso represented about one-third of the Brazilian production and almost half of the "safrinha" corn (second-crop corn) in 2017/2018. Since it is in the center of South America, the corn produced in Mato Grosso faces logistical challenges to be transported to ports and then exported. As a consequence, corn prices in this region are lower when compared to other states, being an alternative to be used as a feedstock for ethanol production [7]. Currently, corn ethanol corresponds to $2 \%$ of Brazilian ethanol. In 2017, 305 million liters were produced in 4 plants in Goias and Mato Grosso states. These states increased the production to 830 million liters in 2018, and 6 new plants are expected to start operation in these states by 2021 [15]. In the corn ethanol production process the ground corn is diluted with water until $32-35 \%$ of dry matter [16,17]; thus, for each ton of corn, two cubic meters of water are used, which is usually supplemented with nutrients to promote yeast growth and stimulate fermentation [18].

Recently, researchers and sugarcane producers are becoming more interested in a type of cane known as energy cane (Saccharum spp.). If the energy cane is harvested with leaves and the top, it can increase the total biomass by 100\%, however, with a loss of $25 \%$ to $35 \%$ of sucrose [19,20]. In Brazil, the sugarcane stem yield is about 80 tons per hectare [21], generating $250 \mathrm{~kg}$ of bagasse per ton of sugarcane stem processed, that is, about 20 tons of bagasse per hectare. The energy cane can produce four times more bagasse and potential energy for cogeneration per hectare than the sugarcane [22,23]. The energy cane juice is mainly composed of water and has a lower purity and sugar and minerals content than sugarcane juice, however, due to its high yields, provides more sugars per hectare than the traditional sugarcane $[24,25]$.

The concentration of corn production in Mato Grosso and the logistics challenges improve the economic viability of ethanol production in the region, bringing companies that are investing in new plants. Several crops are well adapted and used as biomass for energy generation in Brazil, and due to its high biomass yield, energy cane has been gaining more prominence. In this context, we hypothesized that the energy cane would be a viable option to be integrated with the corn ethanol production in Brazil because (i) its bagasse can supply the industry energy demand, and (ii) its juice could replace the water in the corn dilution, providing sugars and reducing the amount of corn and enzymes used in the industry. However, in the literature, there are few studies on the fermentation of energy cane juice [26] and no study proposing the integration of cane juice with corn was found. Therefore, the effects of using the energy cane juice to dilute the corn in the fermentation process are unknown. For these reasons, this study aimed to assess the influence of the energy cane juice on the fermentation efficiency of three treatments: only corn, only energy cane juice, and corn plus energy cane juice. The yeast cell viability; initial and final contamination; residual sugars; and fluoride, chloride, sulfate, nitrate, and phosphate contents were also analyzed. We performed a principal component analysis (PCA) and the correlations between these parameters. 


\section{Materials and Methods}

\subsection{Materials}

The experiments were conducted in July 2017 at the Sugar and Alcohol Laboratory of the Department of Agri-Food Industry, Food and Nutrition (LAN) of the College of Agriculture "Luiz de Queiroz", from the University of São Paulo (ESALQ/USP), in Piracicaba.

In the center-west of Brazil, the corn used for ethanol production is the crop surplus of the rotation with soybean, and there are no specific varieties for corn ethanol production [27]. The corn we used was purchased at an agricultural store in the municipality of Piracicaba, around ESALQ. The corn grains were subjected to hammer milling to obtain fragments with particle size between 2 and $4 \mathrm{~mm}$, by using an automatic sieve. Moisture and starch content of the ground corn were measured according to methods described in the following subsections.

The energy cane was harvested in May 2017 in an experimental station located in Rio Claro, in the state of São Paulo, near Piracicaba. The energy cane was harvested in the morning and transported directly to the ESALQ/USP Sugar and Alcohol Sector, to avoid any influence of contamination at harvest time. In the Sugar and Alcohol laboratory, the energy cane was defibrated and its juice extracted in a hydraulic press. Just after being extracted, the juice underwent a clarification process. It was boiled to separate lighter particles and filtered through a cotton filter. The filtrate was directed to a 9 L glass canister and $2.5 \mathrm{~g} / \mathrm{L}$ of monobasic sodium phosphate was added. After the reagent was added, the container was sealed and autoclaved at $125^{\circ} \mathrm{C}$ with $1 \mathrm{~kg}$-force per $\mathrm{cm}^{-2}$ of pressure for $25 \mathrm{~min}$ to be sterilized. After $48 \mathrm{~h}$ resting, the container was opened, the supernatant was siphoned, directed to another glass recipient, and again autoclaved, to be stored until the moment of the experiments [28]. A sample of this supernatant was taken to analyze the total sugar content (sum of glucose, fructose, and 1.05 times sucrose).

\subsection{Experimental Design}

Three treatments were used in this study: energy cane treatment, corn treatment, and proposed treatment.

The energy cane treatment (ECT) was the control using only energy cane juice. The stored energy cane juice had $10.5 \%$ of initial sugar content. For use in ECT, stored energy cane juice was concentrated by evaporation at $105^{\circ} \mathrm{C}$, so that the initial concentration of reducing sugars in ECT was $20 \%$.

The corn treatment (CT) was performed following the flowchart of traditional ethanol production in US corn ethanol plants [17] and summarized in Figure 1. The ground corn was diluted with water. The proposed treatment (PT) process was the same as the one used for the corn treatment (Figure 1). However, the ground corn was diluted with energy cane juice (10.5\% sugar content). Before the dilution, water and energy cane juice were heated to $55^{\circ} \mathrm{C}$, in order to raise the temperature of the corn suspension and bring it closer to the optimal for alpha-amylase enzyme. After that, for both treatments the suspension was heated to $85^{\circ} \mathrm{C}$ in an 80 -rpm-rotation water bath, when alpha-amylase $(0.05 \% v / v)$ was added according to the volume of the reaction reactor, remaining under these conditions for $90 \mathrm{~min}$, completing the gelatinization step. After the first stage of hydrolysis, the medium was autoclaved. Subsequently, $0.05 \%(v / v)$ of amyloglucosidase and $1 \%(\mathrm{~m} / \mathrm{v})$ of yeast were added, according to the total volume of the reactor, at $30^{\circ} \mathrm{C}$ and in an 80 -rpm rotation. The saccharification was performed simultaneously with fermentation, gradually releasing fermentable sugars for yeast consumption. 

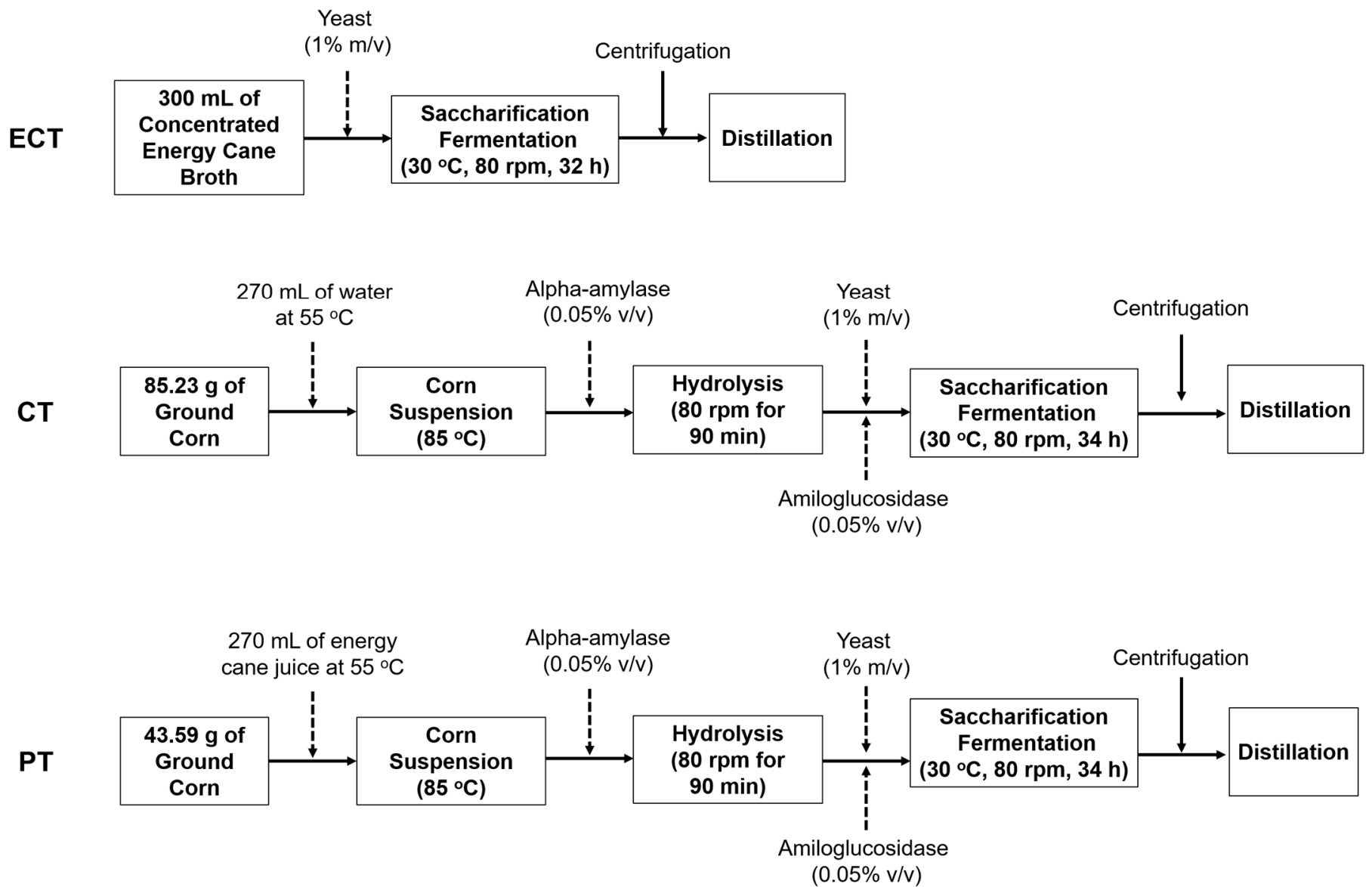

Figure 1. Diagrams summarizing the processes performed in the treatments with energy cane (ECT), with corn (CT), and mixing energy cane juice and corn (PT).

The amounts of corn added to the CT and PT were calculated based on the starch content of the corn $(70.2 \%)$. Preliminary studies were performed using the same concentrations of enzymes in order to determine the efficiency of the enzymes in converting the starch into glucose. The amount of corn of each reactor was calculated to have $20 \%(\mathrm{~m} / \mathrm{v})$ of sugars available to the yeast during the fermentation process. The alpha-amylase (BAN ${ }^{\mathrm{TM}}$ $480 \mathrm{~L}$, specific activity $\geq 250$ units $/ \mathrm{g}$ ) and the amyloglucosidase (AMG ${ }^{\mathrm{TM}} 300 \mathrm{~L}$, specific activity $\geq 260$ units/g) were from Novozymes. The corn treatment had $28 \%$ of corn (dry matter), close to values reported in the literature [16,17].

The experiment was carried out in a randomized complete block design. Three blocks were carried out with five replications of each treatment in each block. All the 45 experimental units had a working volume of $300 \mathrm{~mL}$. At the beginning of the fermentation, the reactors were inoculated with $1 \%(\mathrm{~m} / \mathrm{v})$ of live Fleischmann lineage yeast. Before inoculating the yeast, all treatments were autoclaved to reduce any influence on fermentation caused by contamination. The experimental units had a standard rotation of $80 \mathrm{rpm}$ in a temperature-controlled environment at $30^{\circ} \mathrm{C}$. After fermentation began, every two hours, a random experimental unit of each treatment was weighed to control the fermentation rate, since the reduction of the total reactor weight can be related to carbon dioxide generation and, consequently, the fermentation rate; based on it, the fermentation of each reactor was ceased when its weight became constant. Subsequently, the fermented juice was centrifuged and the supernatant stored at $-4{ }^{\circ} \mathrm{C}$.

\subsection{Analytical Methods}

The following parameters were analyzed during the described procedures. 


\subsubsection{Yeast Viability}

Yeast viability was determined by differential staining of living cells by $0.1 \%$ methylene blue solution and counting of the dead, live, and viable shoots by light microscopy according to the methodology described by $[29,30]$. This analysis was performed at the beginning, the middle, and the end of the fermentation cycle.

For the $0.1 \%$ methylene blue solution, $0.025 \mathrm{~g}$ of methylene blue dye, $5 \mathrm{~g}$ of sodium citrate, and $25 \mathrm{~mL}$ of distilled water were used. Methylene blue and sodium citrate were weighed on an analytical balance and then added to distilled water in a conical flask. After the complete dissolution of the solids, the solution was transferred to an amber labeled flask.

For cell viability counting, $0.5 \mathrm{~mL}$ of the yeast (wine) suspension was collected and added to $9.5 \mathrm{~mL}$ distilled water. After dilution, $0.3 \mathrm{~mL}$ was transferred to the tube and $0.3 \mathrm{~mL}$ of $0.1 \%$ methylene blue solution was added. The mixture was homogenized on the tube shaker for $10 \mathrm{~s}$. With the aid of an automatic pipette, $0.1 \mathrm{~mL}$ of the prepared sample was transferred to the Neubauer chamber and covered with a coverslip. The yeast cells viability counts were performed with the dilution of the wine using a Neubauer chamber in an optical microscope (Nikon, $400 \times$ ).

\subsubsection{Anions, Glucose, Fructose and Sucrose Content}

Analyzes were performed according to the methodology developed by Application Work AWI CBR-0022-082012 [31]. The equipment used was an ion chromatograph, model 930 Compact IC Flex, equipped with an Amperometric Detector.

Samples were collected, diluted, and filtered on $0.45 \mu \mathrm{m}$ Durapore porosity filter units. Then, $0.25 \mu \mathrm{L}$ of the sample was injected into the ion chromatograph for glucose, fructose, and sucrose analysis. The following chromatographic system was used: Column Metrosep Carb 1-150/4.0, the eluent was $200 \mathrm{mM} \mathrm{NaOH}$ solution, with a $1.0 \mathrm{~mL} / \mathrm{min}$ flow under $35^{\circ} \mathrm{C}$ for $9 \mathrm{~min}$.

\subsubsection{Bacterial Contamination}

Although all the feedstocks were sterilized before fermentation, the bacterial contamination was assessed to ensure that the substrate was not contaminated before and during the fermentation process. After the beginning and at the end of the fermentation, $1 \mathrm{~mL}$ samples were collected from each experimental unit and diluted 1000 and 100,000 times, respectively. In a vertical laminar flow chamber, with sterilized materials, it was inoculated in Petri dishes containing YPD media, composed of $1 \%$ yeast extract, $2 \%$ peptone, $2 \%$ glucose [32], 2\% agar, and $10 \mathrm{ppm}$ hexanamide [33], to avoid the growth of eukaryote cells, such as fungus, allowing only the growth of prokaryote, in this case, contaminant bacteria. It was incubated at $35^{\circ} \mathrm{C}$ for $48 \mathrm{~h}$, and after this period, the number of colony-forming units (CFU) was counted.

\subsubsection{Starch Content in the Corn}

Starch content was estimated indirectly by determining the soluble reducing sugars content. To this end, $0.1 \mathrm{~g}$ of ground corn was diluted in $20 \mathrm{~mL}$ of water, followed by enzymatic hydrolysis with extra enzymes (20 times more than recommended), under the conditions mentioned in Section 2.2, followed by chemical hydrolysis as described by [34].

The diluted solution had the glucose content determined by ion chromatography, following the steps of Section 2.3.2. Based on the dilution factor and the starch to glucose conversion rate, the glucose content of the solution was converted to starch content based on dry matter.

\subsubsection{Alcohol Content}

For the analysis of alcohol content, $25 \mathrm{~mL}$ of sample was collected from each experimental unit, at the beginning and end of the fermentation. This sample was distilled in a micro-distiller MA 012/1 (Marconi, Piracicaba, Sao Paulo, Brazil). After the sample was 
distilled, it was analyzed using the Schmidt Haensch Digital Densimeter EDM 4000. Using a $25 \mathrm{~mL}$ volumetric pipette, the sample was transferred to the distillation chamber, with distilled water subsequently washed to the place where the sample was placed. After the boiler water had boiled, the boiler and sample collector taps were closed, and the thermostat was set to work temperature. Distillation was conducted until the $25 \mathrm{~mL}$ volume was collected in a volumetric flask placed on the distiller condenser outlet valve. For the densimeter to reach the working conditions, it was first necessary to adjust the temperature to $20^{\circ} \mathrm{C}$ with a deviation of $0.05^{\circ} \mathrm{C}$. After temperature stabilization, air and water were injected to calibrate the equipment $[35,36]$.

After the densimeter had reached working conditions, the sample aliquots were transferred to the sample receiver tube, taking care that no air bubbles formed inside the reading tube. After completing the tube with the sample, the start button was pressed and the density value on the screen was observed. This value was later used to calculate the value in ${ }^{\circ} \mathrm{GL}$ by converting the read density to the alcohol concentration of the solution in $\% v / v$ taken from a relative density conversion table at $20^{\circ} \mathrm{C} / 20^{\circ} \mathrm{C}$.

\subsection{Fermentation Yield and Efficiency}

The practical yield (Yp) is the amount of ethanol obtained from $100 \mathrm{~g}$ of sugars supplied in the juice. Its calculation involves determining the mass of sugars supplied to the reactor and the mass of ethanol produced:

$$
\text { Yield }(\mathrm{Yp})=(\mathrm{mL} \text { of final ethanol } / \mathrm{g} \text { of sugars supplied }) \times 100
$$

The industrial fermentation process will be more efficient as it approaches GayLussac's optimal yield. Thus, fermentation efficiency is defined as the percentage ratio between practical and theoretical yields (51.11 $\mathrm{g}$ of ethanol/100 $\mathrm{g}$ of sugars):

$$
\eta P(\%)=\left(\frac{Y P}{Y t}\right) \cdot 100
$$

\subsection{Statistics}

All data collected was digitized and processed on Microsoft Excel. A summary spreadsheet with the data of each variable of each experimental unit was made and input into JMP Pro 15 (JMP, version Pro 15, SAS Institute Inc., Cary, NC, USA 1989-2019) that was used to perform the statistical analysis. Analysis of variance (ANOVA) considering the main effects of treatment on the parameters analyzed. Tukey test was used to separate means at $p<0.05$. JMP Pro 15 was also used to perform the principal component analysis (PCA) and the correlations of the parameters assessed for the corn ethanol treatment and the proposed treatment.

\section{Results}

\subsection{Water and Corn Use}

External water was not used in the proposed treatment, which had the corn diluted in the energy cane juice. Besides the water, about $89 \%$ of its composition, the energy cane also provided fermentable sugars, about $10.5 \%$ of its composition, and reduced the amount of corn used in the PT treatment (Table 1).

Table 1. Water added, corn used, and grams of corn need to produce one milliliter for ethanol for the corn treatment (CT) and the proposed treatment (PT).

\begin{tabular}{cccc}
\hline & $\begin{array}{c}\text { Water Added in Each } \\
\text { Reactor }(\mathbf{m L})\end{array}$ & $\begin{array}{c}\text { Corn Used in Each } \\
\text { Reactor }(\mathbf{g})\end{array}$ & $\begin{array}{c}\text { g of Corn per } \mathbf{m L} \text { of } \\
\text { Ethanol }\end{array}$ \\
\hline CT & 270 & 85.23 & 2.53 \\
PT & 0 & 43.59 & 1.21 \\
\hline
\end{tabular}




\subsection{Final Yeast Viability, Residual Sugars, and Contamination}

At the end of the fermentation process, samples of yeast were collected from each experimental unit. The final yeast viability of the ECT treatment, with only energy cane juice, was the highest, $91.91 \%$. The proposed treatment had the final viability of $88.26 \%$, and for the corn treatment, the viability was $85.94 \%$. However, the final viability had no significant difference among the treatments when compared using the Tukey test at a $5 \%$ significance level (Table 2).

Table 2. Final yeast viability, residual sugars and contamination of fermented energy cane juice (ECT), corn (CT), and corn plus energy cane (PT).

\begin{tabular}{cccc}
\hline Treatment & Yeast Viability (\%) & Residual Sugars (\%) & CFU/mL (103) \\
\hline ECT & $91.91 \pm 3.56 \mathrm{a}$ & $0.27 \pm 0.04 \mathrm{~b}$ & $7.69 \pm 6.03$ \\
CT & $88.26 \pm 4.81 \mathrm{ab}$ & $0.55 \pm 0.16 \mathrm{a}$ & $6.18 \pm 4.38$ \\
PT & $85.94 \pm 5.49 \mathrm{~b}$ & $0.33 \pm 0.16 \mathrm{ab}$ & $6.04 \pm 4.58$ \\
\hline
\end{tabular}

Data were subjected to one-way ANOVA, and differences among means were compared using. Different letters indicate a significant difference between treatments $(\alpha=0.05)$.

The residual fermentable sugars were considered as the sum of the concentrations of glucose, fructose, and sucrose (times 1.05, due to a hydrolysis factor). The corn treatment had the highest residual sugars concentration, $0.55 \%$, which was significantly different when compared with the ECT (Table 2).

At 100,000 times dilution, no colony-forming was found in Petri dishes at the beginning, and at the end of the fermentation process. At 1000 dilution, no colony was found at the beginning. At the end of the fermentation, colonies grew in the Petri dishes, but no significant difference was found in the Tukey test at a $5 \%$ significance level (Table 2).

\subsection{Final Alcohol Content and Fermentation Yield and Efficiency}

Significative differences were found among the treatments for the alcohol content, yield, and efficiency (Table 3). The proposed treatment (PT) had significantly higher final alcohol content $(12.0 \%)$, Yield $(60.2 \mathrm{~mL} / 100 \mathrm{~g})$, and efficiency $(90.8 \%)$. The corn treatment (CT) was significantly higher than the energy cane treatment (ECT) in the parameters of final alcohol content, yield, and efficiency, $11.2 \%, 55.9 \mathrm{~mL} / 100 \mathrm{~g}$, and $86.4 \%$, respectively. The energy cane treatment (ECT) final alcohol content, yield, and efficiency were $10.5 \%$, $52.2 \mathrm{~mL} / 100 \mathrm{~g}$, and $80.6 \%$, respectively.

Table 3. Final alcohol content and fermentation yield and efficiency of energy cane juice (ECT), corn (CT), and corn plus energy cane (PT).

\begin{tabular}{cccc}
\hline Treatment & Alcohol Content $\left(\mathbf{v} \cdot \mathbf{v}^{-1}\right)$ & Yield $\left(\mathbf{m L 1 0 0} \cdot \mathbf{g}^{-1}\right)$ & Efficiency (\%) \\
\hline ECT & $10.5 \pm 0.22 \mathrm{c}$ & $52.2 \pm 1.08 \mathrm{c}$ & $80.6 \pm 1.67 \mathrm{c}$ \\
CT & $11.2 \pm 0.47 \mathrm{~b}$ & $55.9 \pm 2.34 \mathrm{~b}$ & $86.4 \pm 3.61 \mathrm{~b}$ \\
PT & $12.0 \pm 0.39 \mathrm{a}$ & $60.2 \pm 1.97 \mathrm{a}$ & $90.8 \pm 3.04 \mathrm{a}$ \\
\hline
\end{tabular}

Different letters indicate a significant difference between treatments $(\alpha=0.05)$.

\subsection{Anions Content in the Fermented Juice}

The ECT had significantly greater fluoride, chloride, sulfate, and phosphate contents when compared to CT and PT. PT had the greatest nitrate content, and greater contents of phosphate, chloride, and fluoride when compared to the CT (Table 4). 
Table 4. Fluoride, chloride, sulfate, nitrate, and phosphate content of energy cane juice (ECT), corn (CT), and corn plus energy cane (PT).

\begin{tabular}{cccccc}
\hline & Fluoride & Chloride & Sulfate & Nitrate & Phosphate \\
\hline ECT & $116 \pm 3 \mathrm{a}$ & $1969 \pm 71 \mathrm{a}$ & $1244 \pm 32 \mathrm{a}$ & $3 \pm 1 \mathrm{~b}$ & $3547 \pm 95 \mathrm{a}$ \\
CT & $10 \pm 1 \mathrm{c}$ & $318 \pm 15 \mathrm{c}$ & $461 \pm 6 \mathrm{~b}$ & $0 \pm 0 \mathrm{c}$ & $347 \pm 59 \mathrm{c}$ \\
PT & $71 \pm 1 \mathrm{~b}$ & $1011 \pm 28 \mathrm{~b}$ & $192 \pm 10 \mathrm{c}$ & $17 \pm 1 \mathrm{a}$ & $1948 \pm 157 \mathrm{~b}$ \\
\hline
\end{tabular}

All data were subject to the Tukey test at a $\%$ significance level.

\subsection{Principal Component Analysis (PCA) and Correlations between CT and PT}

On the principal component analysis (PCA) on correlations, component 1 and component 2 corresponded to $62.3 \%$ of the total variability. Chloride was the only parameter in the quarter $\mathrm{C} 1-$ and $\mathrm{C} 2-$. Residual sugars and sulfate were placed in the same quarter, $\mathrm{C} 1-$ and $\mathrm{C} 2+$. Final contamination, fluoride content, and final yeast cell viability were in the quarter $\mathrm{C} 1+$ and $\mathrm{C} 2+$. Fermentation efficiency and nitrate and phosphate content were in the quarter $\mathrm{C} 1+$ and $\mathrm{C} 2-$ (Figure 2).

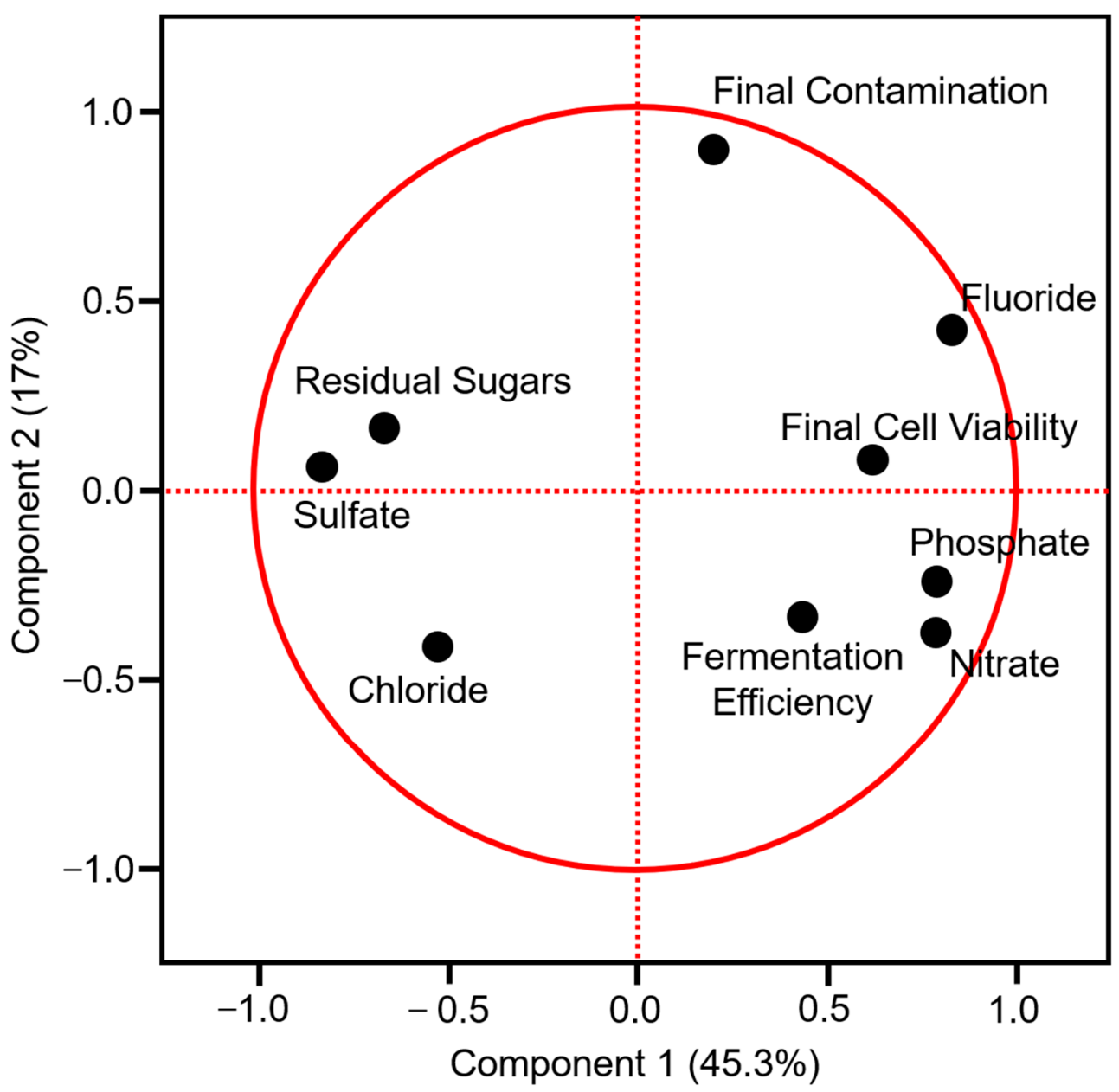

Figure 2. Principal component analysis (PCA) on correlations of fermented substrates parameters of corn ethanol (CT) and corn ethanol integrated with energy cane (PT) and fermentation efficiency.

The fermentation efficiency was positive and significantly correlated with fluoride $(p=0.0158)$, nitrate $(p=0.0303)$, and phosphate $(p<0.01)$ contents, and negative and significantly correlated with residual sugars $(p<0.01)$ and sulfate content $(p=0.0396)$. The residual sugar was negative and significantly correlated with fluoride $(p<0.01)$, nitrate $(p<0.01)$, and phosphate $(p<0.01)$ contents, and positive and significantly correlated with sulfate $(p<0.01)$ content. Final yeast viability and nitrate content were positive and signifi- 
cantly correlated. Fluoride was positive and significantly correlated with nitrate $(p=0.01)$ and phosphate $(p<0.01)$ contents and negatively correlated with chloride $(p=0.02)$ and sulfate $(p=0.01)$ contents. Nitrate was negative and significantly correlated with sulfate $(p=0.01)$ and phosphate $(p<0.01)$. Sulfate and phosphate were negatively correlated $(p<0.01)$ (Table 5).

Table 5. Correlations between the characteristics of the fermented substrates characteristics of corn ethanol (CT) and corn ethanol integrated with energy cane (PT) and fermentation efficiency.

\begin{tabular}{|c|c|c|c|c|c|c|c|c|c|}
\hline & Effic. & R.S. & Contam. & Viab. & Fluor. & Chlor. & Sulf. & Nitr. & Phos. \\
\hline Effic. & 1 & & & & & & & & \\
\hline R.S. & $-0.34^{*}$ & 1 & & & & & & & \\
\hline Contam. & -0.03 & -0.07 & 1 & & & & & & \\
\hline Viab. & -0.15 & -0.06 & -0.2 & 1 & & & & & \\
\hline Fluor. & $0.73^{*}$ & -0.97 * & 0.41 & 0.63 & 1 & & & & \\
\hline Chlor. & -0.24 & 0.34 & -0.12 & -0.31 & -0.60 * & 1 & & & \\
\hline Sulf. & -0.66 * & 0.88 * & -0.25 & -0.37 & -0.98 * & 0.23 & 1 & & \\
\hline Nitr. & 0.80 * & $-0.82 *$ & -0.17 & $0.85 *$ & $0.80 *$ & -0.26 & $-0.88 *$ & 1 & \\
\hline Phos. & $0.99 *$ & -0.97 * & -0.01 & 0.33 & 0.99 * & -0.35 & -0.95 * & $-0.86^{*}$ & 1 \\
\hline
\end{tabular}

Effic.: fermentation efficiency; R.S.: residual Sugar; Contam.: final contamination; Viab.: final cell viability; Effic.: fermentation efficiency; Fluor.: fluoride; Chlor.: chloride; Sulf.: sulfate; Nitr.: nitrate; Phos.: phosphate. ${ }^{*}$ indicates a significant correlation between parameters $(p<0.05)$.

\section{Discussion}

The same procedures were used in the corn treatment $(\mathrm{CT})$ and in the proposed treatment (PT). The only difference was that in the PT energy cane juice was added instead of water, reducing the amount of corn added to the reactor (Figure 1.) Based on the corn starch content, the energy cane juice sugar content, and the volume of the reactor, the proportions were calculated. To this end, for PT, $280 \mathrm{~mL}$ of sugarcane juice $(10.5 \%$ of sugars) was added, providing $29.4 \mathrm{~g}$ of sugar to the reactor. The remaining $30.6 \mathrm{~g}$ needed to complete $60 \mathrm{~g}$ of sugar in the reactor was provided by corn. The required corn mass was calculated considering that $100 \mathrm{~g}$ of corn used in this experiment had $70.2 \mathrm{~g}$ of glucose after the hydrolysis process. Thus, $43.59 \mathrm{~g}$ of corn provides the remaining $30.6 \mathrm{~g}$ to complete $20 \%$ of ART in the reactor. To CT, $60 \mathrm{~g}$ of sugar was needed to achieve $20 \%$ of sugar content in the reactor, so $85.23 \mathrm{~g}$ of corn was added for each experimental unit. Preliminarily, it can already be considered that the integration of energy cane with corn reduces water use at the plant and the amount of corn needed from $85.23 \mathrm{~g}$ to 43.59 , almost half, and reduces the amount of water used in the plant. The $\mathrm{CP}$ treatment produced, on average, $11.19 \mathrm{~mL}$ of ethanol for each $100 \mathrm{~mL}$ of the reactor $(90 \mathrm{~mL}$ of water and $28.41 \mathrm{~g}$ of corn). For each $\mathrm{mL}$ of ethanol produced in this treatment, $8.04 \mathrm{~mL}$ of water and $2.53 \mathrm{~g}$ of corn were needed. PT produced on average $12.03 \mathrm{~mL}$ of ethanol for each $100 \mathrm{~mL}$ of the reactor (43.59 $\mathrm{g}$ of corn). For each $\mathrm{mL}$ of ethanol produced, $1.21 \mathrm{~g}$ of corn was used. No water was added because it was substituted by the energy cane juice (Table 1 ).

However, due to its composition, mainly composed of water and with a high concentration of sugars (about 15\%), sugarcane is known for bringing contaminants from the field to the mill; probably, with the energy cane it will be no different and may cause negative impacts during the fermentation process. The bacterial contamination can decrease the fermentation yield from 14 to $90 \%$ at levels of $10^{8}$ and $10^{9} \mathrm{CFU} / \mathrm{mL}$ [37], concentrations greater than the ones obtained in this study (at $10^{5}$ dilutions no bacterial colonies were found). Besides that, when found, at $10^{3}$ level, there was no significant difference among the treatments, which was expected, since all the experimental units were sterilized before starting the fermentation process, to avoid that the influence of contamination affects the performance of yeast and, consequently, the objective of the work to analyze the effect on fermentation of sugarcane juice energy integrated with corn. Although studies already show that energy cane being stored for $8 \mathrm{~h}$ at $30{ }^{\circ} \mathrm{C}$ does not affect fermentation [26], future studies may assess the need to sterilize energy cane juice before mixing with corn, 
or whether heating to the gelatinization step of hydrolysis could influence reducing or eliminating bacterial contamination brought on by energy cane.

The final viability had no significant difference among treatments. It is known that ethanol in high concentrations can be toxic to the yeast [38], and at the end of the fermentation process, the sugar concentration is low, which can also negatively affect the yeast. For these reasons, it is common to have residual sugars at the end of the process [38]. Devantier et al. (2005) started a fermentation process of corn ethanol with $25 \%$ of sugars and obtained a $2.5 \%$ residual sugar, that is, $90 \%$ of the initial sugar was consumed during the fermentation process [17]. At this experiment, the initial sugar concentration in the reactors was $20 \%$, and the residual sugars had significant differences among the treatments. The corn ethanol (CT) treatment was the one with higher residual sugar, $0.55 \%$. However, still, $97.25 \%$ of the initial sugar was consumed, a value greater than obtained by Devantier et al. (2005). The proposed treatment (PT) and energy cane treatment did no differ significantly, consuming $98.35 \%$ and $98.65 \%$, respectively.

Although the energy cane treatment had higher sugar consumption, its efficiency was the lowest and significantly different when compared to the other treatments, $80.60 \%$. This was the only treatment that did not have the hydrolysis process; thus, all the sugar was already available at the beginning of the fermentation, creating an unfavorable environment to the yeast, causing osmotic stress. Under stress, it is well known that yeast can divert its metabolic pathway by consuming sugars and producing glycerol instead of ethanol [39]. Thus, the stress caused to yeast by the high concentration of readily available sugars may be the reason for the poor performance of this treatment, despite the high sugar intake.

On CT and PT, saccharification and fermentation were carried out simultaneously, releasing sugar gradually, not causing osmotic stress to yeast. A pre-saccharification can reduce the enzymes' dosage by $10-15 \%$. However, it is not used in the dry-milling industry, since when it is a more complex process and has higher risks of contamination [17]. Normally, during the corn ethanol fermentation, the solution is supplemented with nutrients to promote yeast growth and thus stimulate fermentation [18]. In this experiment, neither CP nor PT was supplemented with nutrients. It may have affected the CT fermentation efficiency that was significantly different when compared to PT, $86.35 \%$, and $90.82 \%$, respectively, and had higher residual sugars. Although it was not supplemented with nutrients, PT had the best performance. Sugarcane is known for the concentration of minerals, normally not being necessary supplements in the fermentation [40]. In this study, the PT had significantly greater contents of fluoride, nitrate, and phosphate (Table 4), which were positively and significantly correlated with the fermentation efficiency (see Table 5 and Figure 2). Thus, it is likely that the energy cane juice, in addition to sugar, also provided minerals that helped in the fermentation performance. These minerals could be concentrated together with DDGS (Dried distiller grains with solubles), providing a nutritionally richer product with higher value and market interest for animal feed, which is in great demand in the state of Mato Grosso for cattle feed.

However, energy cane is still a new technology and is starting to be adopted on a commercial scale; thus, new varieties are being developed and released recently [23] with a high variation of fiber content and juice compositions [41,42]. The harvest date can also significantly affect the energy cane composition [43]. Ceccato-Antonini et al. (2017) claimed to be "the first research to deal with the characteristics of deterioration and fermentability of energy cane juices". In their study, the fermentation efficiencies of two energy canes VG11-X1 and VG11-X2 (initial sugars of $19.5 \%$ and $13.2 \%$ ) were $54.9 \%$ and $56.1 \%$, respectively [26], considerably lower than the value obtained in this study on the ECT, $80.6 \%$. Li et al. (2017) used $2 \%$ of yeast extract on a simultaneous fermentation and saccharification of corn starch for $72 \mathrm{~h}$ and obtained a fermentation efficiency of $84.5 \%$, similar to the fermentation efficiency obtained in this study on the CT [44]. 


\section{Conclusions}

Energy cane showed great potential to be integrated into the corn ethanol production system. The fermentation efficiency significantly increased by $4.8 \%$ when the corn was integrated with the energy cane juice and was positive and significantly correlated to the phosphorus, nitrogen, and fluoride content. Therefore, the introduction of energy cane juice in the corn ethanol production process (i) provides sugars that reduce by almost $50 \%$ the amount of corn used in the ethanol plant, (ii) replaces the water used in the dilution process (2-3 L of water per $\mathrm{kg}$ of corn), (iii) increases the fermentation efficiency by providing nutrients that stimulate the yeast growth and performance. However, there are still some uncertainties regarding the adoption of energy cane in the corn ethanol production process, and future studies may be necessary in order to (i) assess the effects of potential contaminants that the energy cane can bring from the field and the need to sterilize the energy cane juice before diluting the corn; (ii) determine the adaptions needed in the corn ethanol plant to extract and use the energy cane juice, and (iii) assess how the integration with energy cane will affect the energy balance of the corn ethanol.

Author Contributions: Conceptualization, P.S., P.G., and A.S.B.; methodology, P.S., L.M.L.M.P., E.M.d.C., E.d.C.M., R.P.C., M.S., B.C.M. and A.S.B.; formal analysis, P.S., L.M.L.M.P. and A.S.B.; investigation, P.S., L.M.L.M.P., E.M.d.C., E.d.C.M., R.P.C., M.S., B.C.M. and A.S.B.; resources, P.G. and A.S.B.; data curation, P.S. and A.S.B.; writing-original draft preparation, P.S.; writing-review and editing, A.S.B.; visualization, A.S.B.; supervision, A.S.B.; funding acquisition, A.S.B. All authors have read and agreed to the published version of the manuscript

Funding: This research received no external funding.

Institutional Review Board Statement: Not applicable.

Informed Consent Statement: Not applicable.

Data Availability Statement: The data presented in this study are available on request from the corresponding author.

Conflicts of Interest: The authors declare no conflict of interest.

\section{References}

1. UNICA (Brazilian Sugarcane Industry Association-Sugarcane Observatory). Available online: https://www.observatoriodacana. com.br (accessed on 10 November 2019).

2. EIA U.S. Energy Information Administration: Total Energy Monthly Data. Available online: https://www.eia.gov/totalenergy/ data/monthly/\#renewable (accessed on 10 November 2019).

3. RFA (Renewable Fuels Association) 2020 Ethanol Industry Outlook. Available online: www.eenergyadams.com (accessed on 7 February 2021).

4. U.S. Government. Energy Policy Act of 2005-Public Law 109-58; U.S. Government: Washington, DC, USA, 2005.

5. U.S. Government. Energy Independence and Security Act of 2007-Public Law 110-140; U.S. Government: Washington, DC, USA, 2007.

6. EPA Renewable Identification Numbers (RINs) under the Renewable Fuel Standard Program. Available online: https://www.epa. gov/renewable-fuel-standard-program/renewable-identification-numbers-rins-under-renewable-fuel-standard (accessed on 7 February 2021).

7. Woody, K. Brazil: Grain and Feed Annual; USDA: Brasilia, Brazil, 2019.

8. ANP-Brazilian National Agency of Petroleum, Natural Gas, and B. RenovaCalc. Available online: http://www.anp.gov.br/ producao-de-biocombustiveis/renovabio/renovacalc (accessed on 10 November 2019).

9. Grassi, M.C.B.; Pereira, G.A.G. Energy-cane and RenovaBio: Brazilian vectors to boost the development of Biofuels. Ind. Crop Prod. 2019, 129, 201-205. [CrossRef]

10. UNICA. Cane's Bioelectricity in Numbers-January 2017; UNICA: Sao Paulo, Brazil, 2017. (In Portuguese)

11. Goldemberg, J. Ethanol for a sustainable energy future. Science 2007, 315, 808-810. [CrossRef]

12. Macedo, I.C.; Seabra, J.E.A.; Silva, J.E.A.R. Green house gases emissions in the production and use of ethanol from sugarcane in Brazil: The 2005/2006 averages and a prediction for 2020. Biomass Bioenergy 2008, 32, 582-595. [CrossRef]

13. Hill, J. Environmental costs and benefits of transportation biofuel production from food- and lignocellulose-based energy crops. A review. Agron. Sustain. Dev. 2007, 27, 1-12. [CrossRef]

14. FAO. Crop Prospects and Food Situation. Available online: http://www.fao.org/3/ca5327en/ca5327en.pdf (accessed on 10 November 2019). 
15. USDA Brazil: Biofuels Annual. Available online: https://apps.fas.usda.gov/newgainapi/api/report/downloadreportbyfilename? filename=BiofuelsAnnual_SaoPauloATO_Brazil_8-10-2018.pdf (accessed on 10 November 2019).

16. Kurambhatti, C.; Kumar, D.; Rausch, K.; Tumbleson, M.; Singh, V. Ethanol Production from Corn Fiber Separated after Liquefaction in the Dry Grind Process. Energies 2018, 11, 2921. [CrossRef]

17. Devantier, R.; Pedersen, S.; Olsson, L. Characterization of very high gravity ethanol fermentation of corn mash. Effect of glucoamylase dosage, pre-saccharification and yeast strain. Appl. Microbiol. Biot. 2005, 68, 622-629. [CrossRef]

18. Thomas, K.C.; Hynes, S.H.; Ingledew, W.M. Effect of lactobacilli on yeast growth, viability and batch and semi-continuous alcoholic fermentation of corn mash. J. Appl. Microbiol. 2001, 90, 819-828. [CrossRef]

19. Alexander, A.G. The Energy Cane Alternative; Elsevier Scince Ltd.: Amsterdam, The Netherlands, 1985.

20. Matsuoka, S.; Kennedy, A.J.; Santos, E.G.; Tomazela, A.L.; Rubio, L.C. Energy Cane: Its Concept, Development, Characteristics, and Prospects. Adv. Bot. 2014, 2014, 1-13. [CrossRef]

21. FAO FAOSTAT. Available online: http:/ / www.fao.org/faostat/en/\#data/QC (accessed on 10 November 2019).

22. Matsuoka, S.; Bressiani, J.; Maccheroni, W.; Fouto, I. Sugarcane bioenergy. In Sugarcane: Agricultural Production, Bioenergy and Ethanol; Elsevier Inc.: Amsterdam, The Netherlands, 2015; pp. 383-405, ISBN 9780128022399.

23. Sica, P. Sugarcane Breeding for Enhanced Fiber and Its Impacts on Industrial Processes. In Sugarcane; Khan, M.S., Ed.; IntechOpen: London, UK, 2021.

24. Carvalho-Netto, O.V.; Bressiani, J.A.; Soriano, H.L.; Fiori, C.S.; Santos, J.M.; Barbosa, G.V.; Xavier, M.A.; Landell, M.G.; Pereira, G.A. The Potential of the Energy Cane as the Main Biomass Crop for the Cellulosic Industry; Springer International Publishing: Berlin/Heidelberg, Germany, 2014; Volume 1, p. 20.

25. de Souza, R.B.; de Menezes, J.A.S.; de Souza, R.F.R.; Dutra, E.D.; de Morais, M.A. Mineral Composition of the Sugarcane Juice and Its Influence on the Ethanol Fermentation. Appl. Biochem. Biotechnol. 2015, 175, 209-222. [CrossRef]

26. Ceccato-Antonini, S.R.; Bassi, A.P.G.; Paraluppi, A.L.; dos Santos, E.G.D.; Matsuoka, S. Deterioration and fermentability of energy cane juice. Cienc. Rural. 2017, 47. [CrossRef]

27. Barros, S.; Woody, K. Corn Ethanol Production Booms in Brazil; USDA: Brasilia, Brazil, 2020.

28. Braga, V.S. The Influence of Temperature in Conducting Two Fermentation Processes for the Production of Cachaça; University of Sao Paulo: Piracicaba, Brazil, 2006. (In Portuguese)

29. Pierce, J.S. Institute of Brewing: Analysis committee measurement of yeast viability. J. Inst. Brew. 1970, 76, 442-443. [CrossRef]

30. Oliveira, A.; Gallo, C.; Alcarde, V.; Godoy, A.; Amorim, H. Methods for Microbiological Control in Sugar and Alcohol Production (in Portuguese); FERMENTEC/ESALQ/FEALQ: Piracicaba, Brazil, 1996.

31. Eith, C.; Kolb, M.; Seubert, A.; Viehweger, K.H. Practical Ion Chromatography: An Introduction; Methrom: Herisau, Switzerland, 2002.

32. Corbacho, I.; Teixidó, F.; Velázquez, R.; Hernández, L.M.; Olivero, I. Standard YPD, even supplemented with extra nutrients, does not always compensate growth defects of Saccharomyces cerevisiae auxotrophic strains. Anton. Leeuw. Int. J. G. 2011, 99, 591-600 [CrossRef]

33. PubChem Hexanamide I C6H13NO-PubChem. Available online: https://pubchem.ncbi.nlm.nih.gov/compound/hexanamide\# section=GHS-Classification (accessed on 10 November 2019).

34. Rickard, J.E.; Behn, K.R. Evaluation of acid and Enzyme hydrolytic methods for the determination of cassava starch. J. Sci. Food Agric. 1987, 41, 373-379. [CrossRef]

35. Basso, L.C.; De Amorim, H.V.; De Oliveira, A.J.; Lopes, M.L. Yeast Selection for Fuel Ethanol Production in Brazil. FEMS Yeast Res. 2008, 8, 1155-1163. [CrossRef]

36. Silva, L.F.L.F.; Bernardino, C.D.; Ré, F.E.; Furtado, C.H.F.; Amorim, H.V. Analytical Methods for the Control of Alcohol and Sugar Production; Fermentec: Piracicaba, Brazil, 2003.

37. Alterthum, F.; Cruz, M.R.M.; Vairo, M.L.R.; Gambassi, D.M. Effect of contaminating microorganisms of alcoholic fermentation on microdistilleries (in Portuguese). STAB Açúcar Álcool Subprodutos 1984, 3, 42-49.

38. Bai, F.W.; Chen, L.J.; Zhang, Z.; Anderson, W.A.; Moo-Young, M. Continuous ethanol production and evaluation of yeast cell lysis and viability loss under very high gravity medium conditions. J. Biotechnol. 2004, 110, 287-293. [CrossRef] [PubMed]

39. Petrovska, B.; Winkelhausen, E.; Kuzmanova, S. Glycerol Production by Yeasts under Osmotic and Sulfite Stress. Can. J. Microbiol. 1999, 45, 695-699. [CrossRef]

40. Prado, R.D.M.; Caione, G.; Campos, C.N.S. Filter Cake and Vinasse as Fertilizers Contributing to Conservation Agriculture. Appl. Environ. Soil Sci. 2013, 2013. [CrossRef]

41. Moreira, B.R.A.; Viana, R.S.; Lisboa, L.A.M.; Lopes, P.R.M.; Figueiredo, P.A.M.; Ramos, S.B.; Bonini, C.S.B.; Trindade, V.D.R.; Andrade, M.G.O.; May, A. Classifying Hybrids of Energy Cane for Production of Bioethanol and Cogeneration of Biomass-Based Electricity by Principal Component Analysis-Linked Fuzzy C-Means Clustering Algorithm. J. Agric. Sci. 2019, 11, $246-253$. [CrossRef]

42. Viana, R.D.; Moreira, B.D.; May, A.; Miasaki, C.T.; Caraschi, J.C.; Andrade, M.D. Juice technological quality, lignocellulosic physical-chemical attributes and biomass yield from energy cane clones. Aust. J. Crop Sci. 2019, 13, 746-752. [CrossRef] 
43. Knoll, J.E.; Anderson, W.F.; Richard, E.P.; Doran-Peterson, J.; Baldwin, B.; Hale, A.L.; Viator, R.P. Harvest date effects on biomass quality and ethanol yield of new energycane (Saccharum hyb.) genotypes in the Southeast USA. Biomass Bioenergy 2013, 56, 147-156. [CrossRef]

44. Li, Z.; Wang, D.; Shi, Y.C. Effects of nitrogen source on ethanol production in very high gravity fermentation of corn starch. J. Taiwan Inst. Chem. Eng. 2017, 70, 229-235. [CrossRef] 